УДК 339.13

JEL classification: D22, D40, D47, L10

Серебренніков Б. С. канд. економ. наук, доиент ORCID ID: 0000-0002-7315-3839

Національній технічний університет Украӥни "Київський політехнічний інститут ім. Ігоря Сікорського"

\title{
ІНСТИТУЦІЙНО-ПОВЕДІНКОВИЙ ПІДХІД ДО АНАЛІЗУ КОНКУРЕНТНОСТІ РИНКУ ЕЛЕКТРОЕНЕРГІЇ
}

\section{INSTITUTIONAL-BEHAVIORAL APPROACH FOR ELECTRICITY MARKET COMPETITIVENESS ANALYSIS}

Стаття присвячена обтрунтуванню доцільності застосування інституціийноповедінкового підходу до оцінювання та аналізу конкурентності ринку електроенергіі Украӥни. 3 урахуванням особливостей функціонування ринку визначено вихідні науковометодичні положення оцінювання та аналізу його конкурентності, зокрема товарні, географічні та часові межі, суб' сктний склад, структурні елементи та взаємозв 'язки між ними, умови функціонування та поведінки економічних агентів з урахуванням державного регулювання. Доведено, щзо ринок електроенергії України, який складається з оптового, роздрібного ринків, ринків передачі та розподілу електроенергії, завдяки своїй складній структурі, специфічним технічним характеристикам товарної продукиї, технологічним особливостям прочесів виробництва та споживання електроенергї, масштабам державного управління та регулювання, не може розглядатись як типовий товарний ринок на предмет його конкурентності, наявності монопольного (домінуючого) становища та ринкової влади його учасників лише за структурними ознаками. Відносно висока концентрація ринку електроенергії в секторах виробництва та постачання електроенергї як в Украӥні, так $i$ в більшості краӥн Європи на сучасному етапі вважається прийнятною, історично обумовленою та економічно виправданою. Тому для оцінювання конкурентності, визначення та аналізу наявності ринкової влади учасників ринку, зловживання нею, доцільно використовувати поведінкові ознаки конкуренції, які істотним чином визначаються інституційним середовищем ринку. При визначенні суб'єктного складу сегменту виробництва і оптового продажу електроенергії, доцільно виходити не з ознаки права власності, а з ознаки юридччнӧ відокремленості генеруючих компаній. За допомогою інституиійно-поведінкового аналізу доведено, щуо навіть в межах однієї формальної групи (холдингу) генеруючі компанії діють як юридично та комериійно незалежні гравиі, конкурують між собою за обсяги продажу електроенергії в оптовий ринок. При чому у відповідності до правил оптового ринку, чим більше електроенергї вироблятиметься генеруючими компаніями з використанням відновлювальних джерел енергії, яким встановлено "зелений" тариф, та ТЕЦ, тим меншим буде виробництво електроенергї̈ генеруючими компаніями, які працюють за ціновими заявками. Відповідно останні зазнають значної конкуренції від перших та других.

Ключові слова: ринок електроенергії, конкуренція та конкурентність, інституційне середовище, поведінка ринкових агентів, державне регулювання 
The paper is devoted to substantiation of institutional-behavioural approach to assessment and analysis of the Ukraine's electricity market competitiveness. Taking into account the peculiarities of Ukraine's electricity market functioning, initial scientific and methodological provisions of the assessment and analysis of its competitiveness, including commodity, geographical and time frameworks, subject structure, structural elements and interrelations between them, conditions of functioning and behaviour of market agents were specified. It is proved that the Ukraine's electricity market, consisting of wholesale, retail, transmission and distribution markets, due to its complex structure, specific technical characteristics of commodity products, technological features of production processes and consumption of electricity, the scope of governmental regulation, cannot be considered as a typical commodity market for the purpose of assessment of its competitiveness, the presence of a monopoly (dominant) position and market power of its participants using only structural characteristics. The relatively high concentration of electricity market in segments of production and supply in Ukraine and in most European countries at the present stage is considered as acceptable, historically determined and economically justified. Therefore, in order to assess competition, determine and analyse the presence of market power of market participants, abuse of it, it is expedient to use behavioural characteristics of competition, which are essentially determined by institutional environment of the market. In determining the subjective composition of the segment of production and wholesale electricity sales, it is advisable not to derive from the sign of ownership, but from the sign of legal separation of producers. Using institutional and behavioural analysis, it has been proved that even within a single formal group (holding company), producers act as legally and commercially independent players, compete with each other for the volume of sales to the wholesale electricity market. Moreover, in accordance with the rules of Ukraine's wholesale market, the greater the quantity of electricity generated by producers using RES, which has a feed-in tariff, and the CHP, the lower the production of electricity by producers operating on the price bids base.

Keywords: electricity market, competition and competitiveness, institutional environment, behavior of market agents, governmental regulation

Вступ. Конкурентність товарних ринків, як правило, $\epsilon$ засадничою умовою їхньої ефективності, кращого задоволення потреб споживачів, стимулювання розвитку агентів ринків та економічних відносин між ними. Сучасна модель ринку електроенергії України (британська модель "пулу"), запроваджена ще у середині 90-х рp. XX ст., є монопольною по своїй природі, передбачає істотний рівень державного регулювання, а конкуренція в секторах виробництва та постачання є обмеженою. Доцільність реформування ринку електроенергії України на принципах лібералізації економічних відносин є загальновизнаною, об'єктивно обумовленою і вкрай актуальною. Головними завданнями такої трансформації $\epsilon$ забезпечення конкурентності, прозорості, відкритості і недискримінаційності ринку, що має призводити до підвищення його ефективності. Ці завдання, в свою чергу, актуалізують питання удосконалення науково-методичних підходів до оцінювання та аналізу стану конкуренції на ринку електроенергії України.

Традиційно дослідження конкурентності товарних ринків здійснює Антимонопольний комітет України (АМКУ) за допомогою Методики визначення монопольного (домінуючого) становища суб'єктів 
господарювання на ринку [1]. Зокрема в 2015 р. АМКУ провів оцінювання конкурентності ринку електроенергії України [2]. Разом з тим ця Методика обмежується лише структурним аналізом ринку, який зазвичай застосовується у відповідній світовій практиці, проте не розкриває належним чином умови $і$ можливості економічних агентів ринку щодо конкуренції, вплив державного регулювання та інші важливі аспекти, які обумовлюють конкурентність ринку електроенергії. Таким чином отримані в [2] висновки щодо конкурентності ринку електроенергії України, на наш погляд, є дискусійними.

В світовій практиці дослідження конкурентності товарних ринків та ринкової влади економічних агентів в тій чи іншій мірі грунтуються на класичних науково-методологічних підходах Мейсона-Бейна Гарвардської наукової школи функціонування та аналізу галузевих товарних ринків "структура - поведінка - результат" [3], розширеному підході Європейської наукової школи, яка поєднує положення Фрайбурзької, Чиказької, ПостЧиказької та Гарвардської наукових шкіл. Відповідні питання досліджувалися багатьма вітчизняними та зарубіжними вченими і відображені в наукових роботах Шерера Ф., Росса Д., Ханни Л., Кея Дж., Борисенка З., Герасименка А., Точиліна В., Пустовойта О., Ігнатюка А., Лагутіна В. [3-10] та ін. Разом 3 тим зазначені підходи не враховують секторальну специфіку ринків електроенергії. Беручи до уваги особливості функціонування ринку електроенергії в Україні, окремі його виняткові специфічні риси, актуальними $\epsilon$ питання адаптації та обгрунтування науково-методичних аспектів дослідження конкурентності ринку електроенергії в Україні. Зокрема пропонується використовувати інституційно-поведінковий підхід, що має враховувати інституційні умови, обмеження, державне регулювання та свободу економічної діяльності енергокомпаній на ринку електроенергії.

Постановка завдання. Метою статті $є$ обгрунтування доцільності та особливостей застосування інституційно-поведінкового підходу до оцінювання та аналізу конкурентності ринку електроенергії України.

Методологія. Методологічною основою дослідження $\epsilon$ положення теорії галузевих ринків, науково-методичні підходи до оцінювання та аналізу конкурентності ринку електроенергії, зокрема інституційно-поведінковий підхід що грунтується на визначенні інституційних умов та обмежень виробничо-комерційної діяльності агентів ринку.

Результати дослідження. Важливими вихідними науково-методичними положеннями дослідження конкурентності ринку електроенергії та ринкової влади його економічних агентів є товарні, географічні та часові межі ринку, його суб'єктний склад, структурні елементи та взаємозв'язки між ними, умови функціонування та поведінка економічних агентів, регулювання ринку.

Товарні межі ринку визначаються товарною продукцією, яка є об'єктом купівлі-продажу. Чітко окреслити товарні межі ринку електроенергії України 
можна після визначення його структурних елементів.

Під товарним ринком розуміється система товарно-грошових відносин, які виникають між продавцями та покупцями певного товару. При цьому важливо зазначити, що ринок електроенергії України $є$ складним утворенням, що являє собою комплекс взаємопов'язаних, жорстко регульованих державою ринків. Зокрема можна виокремити такі його складові:

1) сегмент виробництва і оптового продажу електроенергї, де існують товарно-грошові відносини між виробниками та єдиним оптовим покупцем електроенергії ДП "Енергоринок" (монопсонія) та сегмент оптового постачання електроенергії, де товарно-грошові відносини виникають між єдиним оптовим продавцем електроенергії ДП "Енергоринок" та постачальними компаніями, а також окремими великими споживачами електроенергії, які $є$ членами оптового ринку електроенергії (ОРЕ) (монополія). Ці два сегменти об'єднані в рамках ОРЕ;

2) роздрібний ринок електроенергї, де товарно-грошові відносини виникають між постачальними компаніями та кінцевими споживачами (олігополія з ознаками монополіі);

3) ринок передачі електроенергіï, де товарно-грошові відносини виникають між виробниками електроенергії та ДП НЕК "Укренерго", що здійснює централізоване диспетчерське управління Об'єднаною енергетичною системою (ОЕС) України та передачу електроенергії магістральними та міждержавними мережами (монополія);

4) ринок розподілу електроенергії локальними електричними мережами (монополія). Зазвичай, напр., в СС, функції розподілу та постачання електроенергії $\epsilon$ відокремлені i виконуються юридично відокремленими розподільчими компаніями, які є власниками мереж (природна монополія) та постачальними (як правило, олігополія), які виконують посередницьку функцію між генеруючими компаніями та кінцевими споживачами. Відповідно і товарно-грошові відносини на цьому ринку мають виникати між розподільчими та постачальними компаніями. Разом 3 тим в Україні ці функції досі не відокремлені, а відтак регіональні розподільчі компанії (обленерго та міськенерго), за якими закріплена певна географічна територія, здійснюють також і постачання електроенергії кінцевим споживачам, що суперечить нормам Другого та Третього енергетичних пакетів СС, які Україна зобов'язана виконати в рамках участі в Енергетичному Співтоваристві та Угоді про асоціацію з СС.

Товарною продукцією, що визначає товарні межі оптового ринку (сегмент виробництва і оптового продажу та сегмент оптового постачання) та роздрібного ринку електроенергії, є стандартизований товар - електрична енергія. Товарною продукцією, що визначає товарні межі ринків передачі та розподілу електроенергії, $є$ послуги з транспортування електричної енергії. 
Оскільки купівля-продаж електричної енергії здійснюється в межах ОЕС України, то географічні межі оптового ринку електроенергії визначаються топологією електричних мереж в межах території України, а також міжнародними електричними перерізами, які використовуються для експорту та імпорту електроенергії.

Купівля-продаж електричної енергії на ОРЕ за Правилами ОРЕ здійснюється на наступну добу, тобто на період не більше однієї календарної доби. Відповідно обсяги і оптові відпускні ціни на електроенергію для виробників, які працюють за ціновими заявками, можуть змінюватись кожної доби залежно від потреб в електроенергії кінцевих споживачів, наявних генеруючих потужностей виробників всіх типів та співвідношення цін виробників у їхніх цінових заявках на наступну добу. Обсяги виробництва електроенергії виробників, які працюють не за ціновими заявками, також може змінюватись кожної доби залежно від потреб в електроенергії кінцевих споживачів, наявних генеруючих потужностей виробників.

За таких правил теоретично часовими межами оптового ринку електроенергії може бути календарна доба. Разом з тим враховуючи, що виробництво і споживання електроенергії здійснюється в часі безперервно в умовах їхнього перманентного збалансування 3 метою забезпечення надійності роботи ОЕС України, а також фактор сезонності, який сильно впливає на:

- обсяг потреб в електроенергії кінцевих споживачів (у робочі та вихідні дні, між сезонами року залежно від погодних умов тощо);

- конфігурацію добового графіку навантаження в ОЕС України;

- величину доступних генеруючих потужностей та обсяг електроенергії, що може бути вироблена окремими виробниками, зокрема ГЕС, ВЕС, СЕС та загальну структуру виробництва електроенергії за типами електростанцій, а відтак і конкурентну структуру ринку оптового постачання електроенергії;

- величину дефіциту генеруючих потужностей та відповідно імпорту електроенергії тощо,

за часові межі оптового ринку електроенергії України можуть бути взяті й інші періоди часу.

Учасниками оптового ринку електроенергії України є:

- виробники електроенергії різних форм власності та способів виробництва (АЕС, ТЕС, ГЕС, ГАЕС, ТЕЦ, ВЕС, СЕС та ін.);

- єдиний оптовий покупець та продавець електроенергії в особі ДП "Енергоринок";

- єдиний оператор передачі електроенергії магістральними та міждержавними мережами та диспетчеризації роботи ОЕС України (ДП НЕК "Укренерго"); 
- постачальні компанії, які здійснюють постачання електроенергії за регульованим тарифом;

- постачальні компанії, які здійснюють постачання електроенергії за нерегульованим тарифом;

- посередницькі компанії, що здійснюють експорт / імпорт електроенергії;

- крупні споживачі електроенергії (при наявності прямих договорів купівлі-продажу електроенергії з ДП "Енергоринок").

Структурна схема ринку електроенергії України представлена на рисунку. Генеруючі компанії продають електроенергію в ОРЕ єдиному оптовому покупцю та продавцю ДП "Енергоринок" по цінам, які встановлюються чи в інший спосіб регулюються Національною комісією, що здійснює державне регулювання у сферах енергетики та комунальних послуг (НКРЕКП). В подальшому ДП "Енергоринок" здійснює оптове постачання електроенергії постачальним компаніям та окремим крупним споживачам, які $\epsilon$ членами ОРЕ. Постачальні компанії продають електроенергію кінцевим споживачам на роздрібному ринку чи здійснюють їі експорт.

Генеруючі компанії поділяються на 2 види:

1) ті, які продають електроенергію в ОРЕ за регульованими цінами, що визначаються та затверджуються НКРЕКП (ДП НАЕК "Енергоатом" (експлуатує 4 АЕС), ПАТ "Укргідроенерго" (експлуатує ГЕС та ГАЕС), виробники електроенергії, які використовують ВДЕ і працюють за "зеленим" тарифом (ВЕС, СЕС, малі ГЕС та ін.), ТЕЦ);

2) ті, які працюють за ціновими заявками (генеруючі компанії ТЕС ПАТ "Центренерго", ПАТ "Донбасенерго", ТОВ "ДТЕК Східенерго", ПАТ "ДТЕК Західенерго", ПАТ "ДТЕК Дніпроенерго").

Згідно із ст. 15 "Оптовий ринок електричної енергії України" ЗУ "Про електроенергетику" купівля всієї електроенергії, виробленої на електростанціях, потужність чи обсяг відпуску яких перевищують граничні показники, та весь іiї оптовий продаж здійснюються на ОРЕ України. 


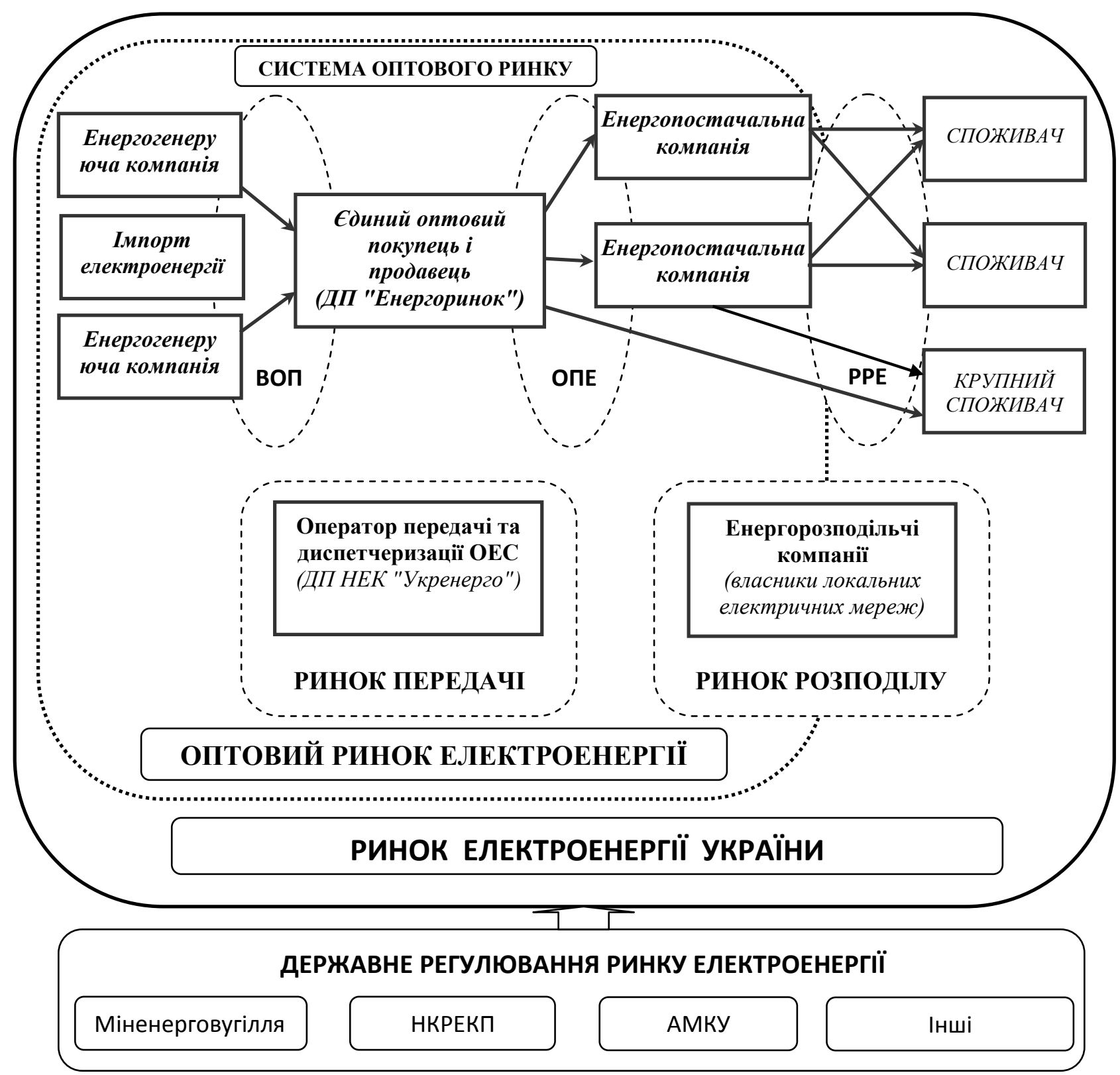

Рисунок - Структурна схема ринку електроенергії в Україні

Примітка: ВОП - сегмент виробництва та оптового продажу електроенергії, ОПЕ - сегмент оптового постачання електроенергії, які є складовими ОРЕ; РРЕ - роздрібний ринок електроенергії; Система оптового ринку - повний набір ліцензій, договорів, положень про експлуатацію та нормативних документів, що регулюють діяльність та функціонування ОРЕ..

Аналізуючи поточну схему функціонування ринку електроенергії України, необхідно зазначити, що Україна не виконала взяті на себе в рамках участі в європейському Енергетичному Співтоваристві та Угоді про асоціацію з СС зобов'язання щодо реформування ринку електроенергії відповідно до Директив 2003/54/€C та 2009/72/€C (на заміну 2003/54/СС) згідно із затвердженим графіком до 01.01.2012 р. Зокрема не відбулося розділення функцій розподілу та постачання електроенергії; не впроваджені двосторонні 
договірні відносини між генеруючими та постачальними компаніями; кінцеві споживачі не набули статусу кваліфікованих, тобто таких, що мають можливість обирати / змінювати постачальника електроенергії; ціноутворення не здійснюється за ринковими принципами, а залишається переважно регульованим НКРЕКП.

Постачальні компанії не мають можливості напряму обирати виробників електроенергії для укладання договорів купівлі-продажу, що спотворює умови конкуренції між останніми. Переважна більшість кінцевих споживачів електроенергії не маючи можливості вибору / зміни постачальника, не мають прямого впливу на відповідні ціни й тарифи. Цей розрив між генеруючими компаніями та кінцевими споживачами щодо можливості вибору останніми (за посередництвом постачальних компаній) більш ефективних виробників не створює стимулів для інноваційного розвитку перших. Тобто споживачі фактично не маючи ринкової влади, не мають змоги стимулювати конкуренцію між виробниками та між постачальниками на ринку електроенергії України і в такий спосіб сприяти структурній трансформації ринку та підвищенню його ефективності. Виконання цього завдання повною мірою покладено на механізми державного регулювання i, частково, саморегулювання.

При цьому споживачі виступають як колективний суб'єкт, формуючи попит на електроенергію, істотно впливаючи таким чином на рівень оптової ринкової ціни. Між ними і виробниками знаходиться оператор системи розрахунків (ДП "Енергоринок"), який перерозподіляє кошти від споживачів до виробників відповідно до алгоритму, встановленого НКРЕКП.

Таким чином, ринок електроенергії України необхідно досліджувати в цілому, усі його сегменти, при цьому не виокремлюючи сегмент ринку, де електроенергія закуповується у виробників єдиним оптовим покупцем (ДП "Енергоринок"), як окремий ринок, оскільки в Україні сегмент генерації (пропозиції) електроенергії є ціноотримуючим, а не ціновстановлюючим, i конкуренція між генеруючими компаніями відбувається не напряму, а через механізм жорсткого державного регулювання.

Оптовий ринок електроенергії Украӥни. Виробники електроенергії на ОРЕ представлені такими основними групами (за типами електростанцій): $\mathrm{BEC}$;

- ДП НАЕК "Енергоатом", яка поєднує 4 AЕС, 1 ГЕС, 1 ГАЕС та 1

- ДП "Укргідроенерго", яка поєднує 9 найбільших ГЕС та ГАЕС;

- генеруючі компанії ТЕС (14 ТЕС) (ПАТ "Центренерго", ПАТ "Донбасенерго", ТОВ "ДТЕК Східенерго", ПАТ "ДТЕК Західенерго" та ПАТ "ДТЕК Дніпроенерго");

- 45 ТЕЦ та інші виробники малої потужності (блок-станції); 
- більше 130 виробників різних форм власності, які виробляють електроенергію з ВДЕ, у тому числі ВЕС, малі ГЕС, СЕС, електростанції, що працюють на біопаливі.

Важливим методологічним питанням при оцінці конкурентності ринку $є$ обгрунтування принципу визначення його суб'єктного складу. Якщо виходити з ознаки права власності на суб'єкти генерації електроенергії, тоді суб'єктний склад сегменту виробництва та оптового продажу електроенергії України виглядатиме так:

- державні генеруючі компанії (ДП НАЕК "Енергоатом", ПАТ "Укргідроенерго", ПАТ "Центренерго", окремі ТЕЦ) як єдиний суб'єкт господарювання;

- група генеруючих компаній ДТЕК (ТОВ "ДТЕК Східенерго", ПАТ "ДТЕК Західенерго" та ПАТ "ДТЕК Дніпроенерго", ПАТ "Київенерго", ТОВ "Вінд Пауер");

- ПАТ "Донбасенерго";

- приватні ТЕЦ (як окремі суб'єкти господарювання);

- приватні генеруючі компанії, що використовують ВДЕ для виробництва електроенергії (як окремі суб'єкти господарювання);

- компанії, що здійснюють імпорт електроенергії (як окремі суб'єкти господарювання);

- інші.

На наш погляд, вищенаведений підхід $€$ хибним, оскільки групи генеруючих компаній, сформовані за принципом належності до одного власника, $\epsilon$ різнорідними і об'єднують виробників, які працюють у принципово різних ринкових умовах щодо ціноутворення та продажу електроенергії в ОРЕ, до того ж конкурують між собою. Тому при визначенні суб'єктного складу ОРЕ України, необхідно виходити не з ознаки права власності, а з ознаки юридичної відокремленості генеруючих компаній, оскільки відповідно до інституційного забезпечення функціонування ОРЕ, зокрема згідно з положеннями Договору членів ОРЕ (ДЧОРЕ), Умовами та Правилами здійснення підприємницької діяльності з виробництва електричної енергії, ліцензіати із виробництва електроенергії не можуть узгоджувати свої дії один із одним, а також субсидіювати споріднені підприємства. Окрім того цими Умовами та Правилами ліцензіатам 3 виробництва електроенергії заборонено взаємодіяти між собою при подачі цінових заявок.

Таким чином, навіть в межах однієї формальної групи (холдингу) суб'єкти виробництва електроенергії ТОВ "ДТЕК Східенерго", ПАТ "ДТЕК Західенерго" та ПАТ "ДТЕК Дніпроенерго", конкурують між собою за обсяги відпуску електроенергії в ОРЕ при щоденній подачі цінових заявок згідно 3 Правилами ОРЕ, що обумовлює покращення їхніх фінансово-економічних показників (обсягів доходу, прибутку, рівня рентабельності) тощо. 
ТОВ "Вінд Пауер" (Ботієвська ВЕС), є виробником електроенергії з ВДЕ, що відпускає електроенергію в ОРЕ за "зеленим" тарифом, затвердженим НКРЕКП. Згідно із ст. 15 ЗУ "Про електроенергетику" ОРЕ України зобов'язаний купувати електроенергію у суб'єктів господарювання, яким встановлено "зелений" тариф, та здійснювати оплату іiї вартості за "зеленим" тарифом незалежно від величини встановленої потужності чи обсягів відпуску. Таким чином, ТОВ "Вінд Пауер", як і будь-який інший виробник електроенергії з ВДЕ, якому встановлено "зелений" тариф, законодавчо має пріоритетне становище на ринку електроенергії щодо гарантованості продажу виробленої ним електроенергії в ОРЕ. Відповідно генеруючі компанії, які працюють за ціновими заявками зазнають конкуренції від перших. При чому за встановлених в ОРЕ правил, чим більше електроенергії вироблятиметься генеруючими компаніями з використанням ВДЕ, яким встановлено "зелений" тариф, тим меншим буде виробництво електроенергії генеруючими компаніями, які працюють за ціновими заявками.

ПАТ "Київенерго" експлуатує дві ТЕЦ. Тариф на відпуск електроенергії в ОРЕ для ТЕЦ затверджується НКРЕКП, а самі ТЕЦ працюють за чітким теплофікаційним графіком, пов'язаним передусім 3 теплопостачанням споживачів в опалювальний період. Супутній продукт - електроенергія продається ними в ОРЕ, що також створює конкуренцію для генеруючих компаній, які працюють за ціновими заявками.

Таким чином, генеруючі компанії, власником яких є держава (ДП НАЕК "Енергоатом", ПАТ "Укргідроенерго", ПАТ "Центренерго", окремі ТЕЦ), та групу генеруючих компаній ДТЕК (ТОВ "ДТЕК Східенерго", ПАТ "ДТЕК Західенерго" та ПАТ "ДТЕК Дніпроенерго"; ТОВ "Вінд Пауер"; ПАТ "Київенерго"; ПАТ "ДТЕК Донецькобленерго" (Миронівська ТЕС)) при оцінюванні та аналізі конкурентності ринку електроенергії України, наявності монопольного (домінуючого) становища та ринкової влади у суб'єктів господарювання не доцільно розглядати як єдині суб'єкти господарювання.

3 урахуванням вище викладеного доцільно вважати, що державні генеруючі компанії ДП НАЕК "Енергоатом", ПАТ "Укргідроенерго", ПАТ "Центренерго", окремі ТЕЦ $\epsilon$ юридично та економічно незалежними суб'єктами господарювання, що здійснюють виробництво електроенергії, продають іï в ОРЕ і перебувають у стані конкуренції між собою та з іншими виробниками. Генеруючі компанії групи ДТЕК, які працюють за ціновими заявками (ТОВ "ДТЕК Східенерго", ПАТ "ДТЕК Західенерго" та ПАТ "ДТЕК Дніпроенерго") зазнають конкуренції як між собою, так і від ТОВ "Вінд Пауер", ПАТ "Київенерго", ПАТ "ДТЕК Донецькобленерго" (Миронівська TEC)) та інших виробників електроенергії, тому їх необхідно розглядати як юридично та економічно незалежні суб'єкти, що здійснюють виробництво електроенергії і продають їі в ОРЕ. 
Висновки. 1. В статті 3 урахуванням особливостей функціонування ринку електроенергії України обгрунтовано вихідні науково-методичні положення оцінювання та аналізу його конкурентності, зокрема товарні, географічні та часові межі ринку, суб'єктний склад, структурні елементи та взаємозв'язки між ними, умови функціонування та поведінки економічних агентів з урахуванням державного регулювання ринку.

2. Ринок електроенергії України, який складається з оптового ринку, роздрібного ринку, ринку передачі та ринку розподілу електроенергії, завдяки своїй складній структурі, специфічним технічним характеристикам товарної продукції (електроенергіï), технологічним особливостям процесів виробництва та споживання електроенергії, масштабам державного управління та регулювання на ньому, не може розглядатись як типовий товарний ринок на предмет його конкурентності, наявності монопольного (домінуючого) становища та ринкової влади його учасників лише за структурними ознаками. Ринок електроенергії України необхідно досліджувати в цілому, усі його сегменти, при цьому не виокремлюючи сегмент ринку, де електроенергія закуповується у виробників єдиним оптовим покупцем (ДП "Енергоринок"), як окремий ринок, оскільки в Україні сегмент генерації (пропозиції) електроенергії $\epsilon$ ціноотримуючим, a не ціновстановлюючим, i конкуренція між генеруючими компаніями відбувається не напряму, а через механізм жорсткого державного регулювання.

3. Відносно висока концентрація ринку електроенергії (порівняно 3 іншими товарними ринками 3 диференційованою товарною продукцією) в секторах виробництва та постачання електроенергії як в Україні, так і в переважній більшості країн Європи на сучасному етапі розвитку вважається прийнятною, історично обумовленою та економічно виправданою. Тому для оцінювання конкурентності, визначення та аналізу наявності ринкової влади у окремих суб'єктів господарювання, зловживання нею на ринку, доцільно використовувати не структурні, а поведінкові ознаки конкуренції, які істотним чином визначаються інституційним середовищем ринку.

4. При визначенні суб'єктного складу сегменту виробництва і оптового продажу електроенергії ОРЕ України, доцільно виходити не з ознаки права власності на суб'єкти генерації, а з ознаки юридичної відокремленості генеруючих компаній, оскільки відповідно до інституційного забезпечення функціонування ОРЕ, зокрема згідно з положеннями ДЧОРЕ, Умовами та Правилами здійснення підприємницької діяльності з виробництва електричної енергії, ліцензіати із виробництва електроенергії не можуть узгоджувати свої дії один із одним, а також субсидіювати споріднені підприємства. Окрім того 
цими Умовами та Правилами ліцензіатам 3 виробництва електроенергії заборонено взаємодіяти між собою при подачі цінових заявок.

5. За допомогою інституційно-поведінкового аналізу доведено, що навіть в межах однієї формальної групи (холдингу) суб'єкти виробництва електроенергії діють як юридично та комерційно незалежні гравці, конкурують між собою за обсяги відпуску електроенергії в ОРЕ, що обумовлює покращення їхніх фінансових показників (обсягів доходу, прибутку, рівня рентабельності економічної діяльності) тощо. При чому у відповідності до правил ОРЕ, чим більше електроенергії вироблятиметься генеруючими компаніями з використанням ВДЕ, яким встановлено "зелений" тариф, та ТЕЦ, які працюють за теплофікаційним графіком, тим меншим буде виробництво електроенергії генеруючими компаніями, які працюють за ціновими заявками. Відповідно останні зазнають значної конкуренції від перших та других.

Перспективами подальших досліджень $є$ розробка підходів до оцінювання і моніторингу конкурентності ринку електроенергії України та ринкової влади його економічних агентів в умовах нової лібералізованої моделі ринку, що має бути запроваджена з 1 липня 2019 p.

\section{Література:}

1. Методика визначення монопольного (домінуючого) становища суб’єктів господарювання на ринку: Розпорядження Антимонопольного комітету України від 5 берез. 2002 p. № 49-p URL: http://zakon2.rada.gov.ua/laws/show/z0317-02.

2. Інформація щодо ознак монопольного (домінуючого) становища на загальнодержавному ринку електричної енергії, яка купується ДП «Енергоринок» 3 метою здійснення діяльності $з$ оптового постачання електричної енергії на оптовому ринку електричної енергії України URL: http://www.amc.gov.ua/ amku/doccatalog $/$ document?id=120029\&schema=main.

3. Шерер Ф., Росс. Д. Структура отраслевых рынков М.: ИНФРА-М, 1997. 698 с.

4. Точилін В., Венгер В. Економічна безпека і ринкова влада. Вісник Тернопільського національного економічного університету. 2008. № 3. С.60-68.

5. Борисенко 3.М. Державне регулювання на ринку цінних паперів 3 точки зору конкурентної політики. Цінні папери України. 2000. №2. С.6.

6. Hanna L., Kay J. Concentration in modern industry: theory, measurement and the UK experience. London: The Macmillan Press, 1977. P. 52-55.

7. Ігнатюк А.І. Галузеві ринки: теорія, практика, напрями регулювання: Монографія. К.: ННЦ IAE, 2010. 465 c.

8. Пустовойт О. Ефективність моделі розвитку внутрішнього ринку України. Економіка України. 2008. № 5. С. 24-36.

9. Герасименко А.Г. Ринкова влада: джерела, масштаби, наслідки: монографія. К.: Київ. Нац. торг.-екон. ун-т, 2014. 600 с.

10. Лагутін В.Д. Інституційні засади державного регулювання конкуренції в Україні. Антимонопольно-конкурентна політика: теорія та практика: збірник наукових праць. Вип. 3. К.: Фенікс, 2008. 260 с. С. 93-108. 